\title{
The effects of line spacing and harvest time on processing yield and root size of carrot for Cenourete ${ }^{\circledR}$ production
}

\author{
Milza M Lana \\ Embrapa Hortaliças, C. Postal 218, 70359-970 Brasília-DF; milza@cnph.embrapa.br
}

\begin{abstract}
The effect of line spacing and harvest time on carrot and Cenourete $^{\circledR}$, a baby carrot-like product, yield were evaluated under conditions of Central Brazil winter. Seeds were sown in order to obtain 6,8 and 10 lines/meter, what corresponded to a distance of 16.6, 12.5 and $10 \mathrm{~cm}$ between lines, respectively. Harvests were made 80, 90 and 100 days after sowing. The cultivars grown were open-pollinated Esplanada and hybrid SugarSnax 54. Root and Cenourete ${ }^{\circledR}$ yield varied with all the main factors and no interaction was significant. The root yield of both cultivars increased with later harvest at each density level. Yield of Esplanada root was only marginally affected by line spacing. Although significant, the effect of plant density on the yield of SugarSnax 54 accounted for less than $5 \%$ of the variation in the data set and differences between means were not significant by Tukey $(\alpha=0.05)$. Cenourete ${ }^{\circledR}$ yield from Esplanada cultivar varied from $9.4 \pm 3.9$ to $15.2 \pm 6.5 \mathrm{t} / \mathrm{ha}$ and from SugarSnax 54 it varied from $9.9 \pm 3.9$ to $18.2 \pm 6.5 \mathrm{t} / \mathrm{ha}$, depending on treatment. Anticipating harvest had a much greater effect in enhancing the recovery of Cenourete ${ }^{\mathbb{B}}$ from carrot roots than increasing plant density. Although it didn't affect total yield, decreasing line spacing to $10 \mathrm{~cm}$ was important to assure that a larger proportion of thinner roots were produced and consequently the production of superior quality Cenouretes ${ }^{\circledR}$ was higher. Harvest time was also important to determine the Cenourete ${ }^{\circledR}$ size since the increase in total production at later harvest was due to a higher proportion of larger Cenouretes ${ }^{\mathbb{R}}$. The best combination line spacing $\mathrm{x}$ harvest time for Esplanada and SugarSnax 54 under the conditions of this experiment will depend whether the interest lies in the production of any or of a particular Cenourete $^{\circledR}$ size.
\end{abstract}

Keywords: Daucus carota, fresh-cut carrot, crop spacing, plant density, harvest time, Cenourete ${ }^{\circledR}$, baby-carrot.

\section{RESUMO}

Efeitos do espaçamento entre linhas e da época de colheita no rendimento industrial e no tamanho de raiz de cenoura para produção de Cenourete $^{\circledR}$

Os efeitos do espaçamento e da data de colheita foram avaliados sob condição de inverno na região Central do Brasil. A semeadura foi feita de modo a obter 6,8 e 10 linhas $/ \mathrm{m}$, o que correspondeu a distâncias entre linhas de 16,6; 12,5 e $10 \mathrm{~cm}$, respectivamente. As colheitas foram realizadas aos 80, 90 e 100 dias após a semeadura. Foram plantadas as cultivares Esplanada, de polinização aberta, e o híbrido SugarSnax 54. A produção de raiz e de Cenourete ${ }^{\circledR}$ foi dependente de todos os fatores estudados e nenhuma interação foi significativa. A produção de raízes de ambas cultivares aumentou à medida que se atrasou a colheita em todos os tratamentos de espaçamento entre linhas. A produtividade da cultivar Esplanada foi apenas marginalmente afetada pelo espaçamento entre linhas. Apesar de significativo, o efeito do espaçamento entre linhas sobre a produção de SugarSnax 54 representou menos de 5\% da variação observada e as diferenças entre médias de tratamento não foram significativas pelo teste de Tukey $(\alpha=0,05)$. O rendimento de Cenourete ${ }^{\circledR}$ a partir de Esplanada variou de 9,4+3,9 a 15,2 $\pm 6,5$ t/ha e a partir de SugarSnax 54 variou de $9,9 \pm 3,9$ a 18,2 $\pm 6,5 \mathrm{t} / \mathrm{ha}$, dependendo do tratamento. A precocidade da colheita teve maior impacto sobre o rendimento de Cenourete ${ }^{\circledR}$ do que o adensamento da cultura. Apesar da ausência de efeito sobre a produção total, o adensamento da cultura para $10 \mathrm{~cm}$ entre linhas foi importante para aumentar a proporção de raízes mais finas, e consequentemente aumentar a produção de Cenourete ${ }^{\circledR}$ de melhor qualidade. A época de colheita também foi importante para determinar o tamanho das Cenouretes ${ }^{\circledR}$, já que a maior produção total em colheitas mais tardias ocorreu às custas da produção de Cenouretes ${ }^{\circledR}$ maiores. A melhor combinação espaçamento entre linhas x época de colheita para Esplanada e SugarSnax 54 nas condições do presente ensaio depende se o interesse da agroindústria é específico para um determinado tamanho ou para qualquer tamanho de mini cenoura.

Palavras-chave: Daucus carota, processamento mínimo, espaçamento, época de colheita, Cenourete ${ }^{\mathbb{R}}$.

\section{(Recebido para publicação em 20 de julho de 2011; aceito em 31 de maio de 2012)} (Received on July 20, 2011; accepted on May 2012)

$\mathrm{T}$ he productivity of Cenourete ${ }^{\circledR}$, a baby carrot-like product, is directly related to the shape and size of the carrot roots (Lana et al., 2007). Cylindrical, long and thin roots result in higher productivity because more segments are obtained per root and less time of abrasion is necessary to shape the segments. Top quality Cenourete $^{\circledR}$ is obtained from segments that have diameter equal to or lower than $25 \mathrm{~mm}$. Segments with a diameter between 25 and $30 \mathrm{~mm}$ can be used to produce a larger Cenourete ${ }^{\circledR}$, which is more suitable for cooking than for consumption as a raw snack. Root segments larger than $30 \mathrm{~mm}$ diameter are considered waste since they result in products with very poor visual quality, which demand high consumption of energy and produce a large volume of waste during peeling in order to attain marketable size.

Hybrid cultivars, with very thin 
and long (around $300 \mathrm{~mm}$ ) roots, are used in the USA for baby carrot production. Under climatic conditions like those found in Central-Southern Brazil, cultivars of those groups can be cultivated only during winter time, due to their susceptibility to foliar diseases. For the best of the authors' knowledge, information about production system of these cultivars under Brazilian conditions is not available in the scientific and technical literature, although personal communication from farmers and seed companies account for its cultivation by some farmers in the Southeast of Brazil, in order to supply few cut and peeled carrot agro industries.

Esplanada is an open pollinated variety, adapted to tropical environment, developed for industrial processing as Cenourete ${ }^{\circledR}$. Although released as a summer variety, it is expected that Esplanada can be cultivated in the main producing regions of Brazil, which have mild winter temperature, all over the year, as the other cultivars of the 'Brasília' group. It was previously reported that Cenourete ${ }^{\circledR}$ yield under conditions of Brazilian summer ranged from 2.4 to $10.7 \mathrm{t} /$ ha depending on the combination of harvest time and between-line spacing (Silva et al., 2008c). This productivity was lower than that reported for hybrid cultivars in the Northern Hemispheres (Lazcano et al., 1998). Despite the differences in edaphoclimatic conditions and in cropping systems, it's clear that the lower recovery of processed carrot from Esplanada cultivar was partly due to its larger diameter and lower length when compared to the cultivars grown in the USA.

Root size varies among cultivars but, within a certain range, it can be adjusted through improvements in the growing system especially population density and harvest time (Salter et al., 1979; Salter et al., 1980; Lazcano et al., 1998; Rajasekaran et al., 2006; Silva et al. $2008 \mathrm{c}$ ). Higher production of thin roots is obtained at a higher density combined with earlier harvest. In a previous report it was hypothesized that a higher recovery of Cenourete ${ }^{\circledR}$ from Esplanada cultivar could be obtained through a decrease in the average root diameter through changes in planting density and harvest time (Silva et al., 2008c).

In the present report, the combined effect of plant density, through variation in line spacing, and harvest time was studied on carrot root and Cenourete ${ }^{\circledR}$ yield obtained from open-pollinated Esplanada and hybrid SugarSnax 54 cultivars. The author is aware that SugarSnax 54 is planted in USA at much higher densities than those studied here. However, the objective of the present study was to evaluate its performance under conditions possible to be reproducible by Brazilian small scale farms and agro industries, which lack the necessary technology for planting at very high densities as experienced abroad.

\section{MATERIAL AND METHODS}

Experiments were carried out at Embrapa Vegetables' experimental field, Brasília, Brazil, during the winters of 2007 and 2008. In each year the combination of three line spacings was evaluated, three harvest times and two cultivars in a randomized block design with 4 replicates.

The seeds were sown by hand in transversal single lines $16.6 ; 12.5$ and $10 \mathrm{~cm}$ apart, in order to obtain the target plant densities of $800,0001,066,000$ and 1,333,000 plants/ha, respectively. Thinning was performed 20 days after sowing leaving 20 plants/meter within each line, so that differences between treatments were solely due to distance between lines. Harvests were made 80,90 and 100 days after sowing. The cultivars grown were Esplanada and SugarSnax 54. Each plot was either 5 $\mathrm{m}$ long (first year) or $4 \mathrm{~m}$ long (second year). Actual plant density and yield were calculated on an overall basis, i.e., considering the area from mid-wheeling to mid-wheeling.

Harvested roots were washed and classified in one of the following classes: waste (split, cracked, lower than $60 \mathrm{~mm}$ long roots); wider diameter lower than $15 \mathrm{~mm}$; wider diameter between 15-25 mm; wider diameter between 25-30 mm; wider diameter higher than $30 \mathrm{~mm}$. Roots in each class were counted and weighed separately. All roots, except for the waste fraction, were pooled and the length of 30 roots chosen randomly was measured using a ruler (1 mm scale). Mean root weight was obtained dividing the total root production by the total number of roots. Afterwards, the roots were cut into $60 \mathrm{~mm}$ long cylindrical segments using the cutter Cortadora Horizontal (Silva et al., 2008a). The root segments were classified in one of the following classes: waste (crowns, tips, segments shorter than $60 \mathrm{~mm}$ and/ or with wider diameter higher than 30 mm; segments with defects such as green parts, cracking, discolouration and misshape); wider diameter lower than $15 \mathrm{~mm}$; wider diameter between 15-25 mm; wider diameter between 25-30 mm. Segments in each class were weighed separately. Abrasion of the root segments to produce Cenourete ${ }^{\circledR}$ was performed with the peeler and polisher Processador de Cenourete ${ }^{\circledR}$ e Catetinho $^{\circledR}$ (Silva et al., 2008b) for the time defined for each segment size, that is 1.5 minute for those smaller than 15 $\mathrm{mm} ; 2$ minutes for those between 15-25 $\mathrm{mm}$ and 2.5 minutes for those between 25-30 mm. All Cenouretes ${ }^{\circledR}$ produced were pooled and classified in one of the following classes: waste (misshapen); wider diameter lower than $15 \mathrm{~mm}$; wider diameter between 15-25 mm; wider diameter between 25-30 mm.

Analysis of variance was performed for each cultivar using PROC GLM from SAS (SAS Institute 9.1 for Windows), considering line spacing and harvest time as sources of variation. The initial analysis was performed for each year separately, followed by a joint analysis for year. The $\mathrm{R}^{2}$ statistics was calculated according to Hatcher \& Stepanski (1994), and it indicates the proportion of the variance in the criterion (independent) variable that is accounted for by the study's predictor (dependent) variable (s). Values of $\mathrm{R}^{2}$ ranged from 0.00 to 1.00 , with larger values indicating larger treatment effect. Mean separations were analysed by Tukey test $(\alpha=0.05)$. Linear regression by PROC CORR from SAS was used to determine the relation between actual 
plant density (number of plants/ha) and root yield (mass of root/ha) pooling the data of all treatments and years and for each combination year $\mathrm{x}$ cultivar $\mathrm{x}$ line spacing $\mathrm{x}$ harvest time combination, based on the approach described in Salter et al. (1979).

\section{RESULTS AND DISCUSSION}

Plant population - The plant density target was 800,000 1,066,000 and $1,333,000$ plants/ha, respectively for the treatments $16.6 \mathrm{~cm}, 12.5 \mathrm{~cm}$ and 10.0 $\mathrm{cm}$ line spacing. Although the density treatments were distinctly different from each other, the target population was not attained and achieved plant density was on average $650,000,832,000$ and $1,038,000$ plants/ha, respectively.

Difficulty in obtaining the desired plant density of the carrot crop is well described in the literature (Salter et al., 1979; Salter et al., 1980). Although the seed emergence rate and percentage were not investigated, it's likely that the lower number of plants at Esplanada plots was at least partially due to the lower physiological quality of the seed compared to SugarSnax 54 (Nascimento et al., 2008).

Root yield - In the first year, cultivar had a significant effect on achieved plant density $(\mathrm{Pr}>\mathrm{F}=<0.001)$ and the number of plants in SugarSnax 54 parcels was higher than in Esplanada ones, for all treatments. Because plant population is one of the main factors which influence root size and root yield, comparisons between the cultivars would be biased by differences in plant population if cultivar was considered a source of variation in the ANOVA. To avoid that bias, the ANOVA for the effects of line spacing, harvest time and year was carried out on the data of each cultivar separately.

Root yield varied with all the main factors. For both cultivars, the total root production in the second year was significantly higher than in the first year $(\operatorname{Pr}>\mathrm{F}=<0.001)$. No interaction between line spacing and harvest time was significant contrary to what has been reported before by Bleasdale (1973) and Salter et al. (1979).

The variation in root yield accounted for by harvest time ( $\mathrm{R}^{2}$ equal to 0.3362 and 0.4742 respectively for Esplanada and SugarSnax 54) was much higher than the variation accounted for by plant density $\left(\mathrm{R}^{2}\right.$ equal to 0.0292 and 0.0486 respectively for Esplanada and SugarSnax 54). The total and processable (total - waste) root yield of both cultivars increased with later harvest (Table 1).

The yield of Esplanada root was only marginally affected by line spacing $(\operatorname{Pr}>F=0.0505)$. Although significant $(\operatorname{Pr}>F=0.0022)$, the effect of line spacing on the yield of SugarSnax
54 accounted for less than $5 \%$ of the variation in the data set $\left(\mathrm{R}^{2}=0.0479\right)$ and difference between means were not significant by Tukey $(\alpha=0.05)$ (Table 1). An upper limit, from which the production decreases due to very high competition, was clearly not achieved. Salter et al. (1980) reported that the carrot yield increased with plant density to a maximum and then declined, the maximum yield being achieved at a higher density with later harvests. However this maximum was achieved at densities in the range 500-700 plants/ $\mathrm{m}^{2}$, much higher than those experienced here (from 80 - 133 plants $/ \mathrm{m}^{2}$ ).

A regression analysis of achieved root density on root yield was carried out as reported by Salter et al. (1980). Because of differences in achieved plant densities within a density treatment, those authors related yields to achieved densities at harvest, rather than to target densities. The same approach was used here in order to verify whether the absence of line spacing effect on root yield was due to high variation within the treatments. Except for harvest at 100 days after sowing (d.a.s.) in the second year, no relation between root yield of SugarSnax 54 cultivar and actual plant density was found (data not shown). Total and processable root yield of cultivar Esplanada, however, was linearly related with achieved plant density in both years, although the adjusted R-square values were very low

Table 1. Effect of line spacing and harvest time on carrot root yield from cultivar Esplanada and SugarSnax 54. Harvest time data are the average \pm standard deviation of 3 line spacings, 2 years and 4 replicates. Line spacing data are the average \pm standard deviation of 3 harvest times, 2 years and 4 replicates (efeito da distância entre linhas e da época de colheita sobre a produção de raízes de cenoura das cultivares Esplanada e SugarSnax 54. Os dados de época de colheita são a média \pm desvio padrão de 3 distâncias entre linhas, 2 anos e 4 repetições. Os dados de distância entre linhas são a média \pm desvio padrão de 3 épocas de colheita, 2 anos e 4 repetições). Brasília, Embrapa Hortaliças, 2007-2008.

\begin{tabular}{lccccc}
\hline & \multicolumn{2}{c}{ Esplanada } & & \multicolumn{2}{c}{ SugarSnax 54 } \\
\cline { 2 - 3 } \cline { 5 - 6 } & Total (kg/ha) & Processable (kg/ha) & & Total (kg/ha) & Processable (kg/ha) \\
\hline 80 d.a.s & $20,324 \pm 7,848 \mathrm{~B}$ & $18,982 \pm 7,710 \mathrm{~B}$ & & $21,183 \pm 6,695 \mathrm{C}$ & $19,765 \pm 6,755 \mathrm{C}$ \\
90 d.a.s & $33,003 \pm 10,863 \mathrm{~A}$ & $31,438 \pm 10,540 \mathrm{~A}$ & & $31,780 \pm 9,358 \mathrm{~B}$ & $30,352 \pm 9,431 \mathrm{~B}$ \\
100 d.a.s & $41,113 \pm 16,273 \mathrm{~A}$ & $39,073 \pm 15,913 \mathrm{~A}$ & & $42,435 \pm 11,354 \mathrm{~A}$ & $40,127 \pm 11,156 \mathrm{~A}$ \\
\hline \multicolumn{5}{c}{ Line spacing** } \\
\hline $16.6 \mathrm{~cm}$ & $29,110 \pm 10,676$ & $27,666 \pm 10,458$ & $30,765 \pm 9,464$ & $29,246 \pm 9,261$ \\
$12.5 \mathrm{~cm}$ & $30,274 \pm 15,958$ & $28,585 \pm 15,473$ & $29,031 \pm 15,061$ & $27,219 \pm 14,743$ \\
$10.0 \mathrm{~cm}$ & $35,055 \pm 16,857$ & $33,240 \pm 16,462$ & $35,600 \pm 12,504$ & $33,678 \pm 12,229$ \\
\hline
\end{tabular}

*Means of harvest time followed by the same letters in the column are not different by Tukey test $(\alpha=0.05)$ (médias de época de colheita seguidas de mesma letra na coluna não diferem pelo teste de Tukey $(\alpha=0,05))$; **Means of line spacing in the column are not different by Tukey test $(\alpha=0.05)$ (médias de distancia entre linhas, na coluna, não diferem pelo teste de Tukey $(\alpha=0,05)$ ). 
Table 2. Effect of harvest time and line spacing on mean root weight of carrot roots from cultivar Esplanada and SugarSnax 54. Harvest time data are the average \pm standard deviation of 3 line spacings, 2 years and 4 replicates. Line spacing data are the average \pm standard deviation of 3 line harvest times, 2 years and 4 replicates (efeito da época de colheita e da distância entre linhas sobre o peso médio de raiz de cenouras das cultivares Esplanada e SugarSnax 54. Os dados de época de colheita são a média \pm desvio padrão de 3 espaçamento entre linhas, 2 anos e 4 repetições. Os dados de espaçamento entre linhas são a média \pm desvio padrão de 3 épocas de colheita, 2 anos e 4 repetições). Brasília, Embrapa Hortaliças, 2007-2008.

\begin{tabular}{|c|c|c|}
\hline & Esplanada root weight (g) & SugarSnax 54 root weight (g) \\
\hline \multicolumn{3}{|c|}{ Harvest time* } \\
\hline 80 d.a.s & $31.0 \pm 8.6 \mathrm{~A}$ & $25.3 \pm 8.5 \mathrm{~A}$ \\
\hline 90 d.a.s. & $44.4 \pm 12.4 \mathrm{~B}$ & $37.4 \pm 12.1 \mathrm{~B}$ \\
\hline 100 d.a.s. & $56.2 \pm 14.8 \mathrm{~B}$ & $49.0 \pm 14.3 \mathrm{~B}$ \\
\hline \multicolumn{3}{|c|}{ Line spacing** } \\
\hline $16.6 \mathrm{~cm}$ & $51.7 \pm 16.4 \mathrm{~A}$ & $48.2 \pm 15.6 \mathrm{~A}$ \\
\hline $12.5 \mathrm{~cm}$ & $40.6 \pm 16.4 \mathrm{~B}$ & $36.8 \pm 15.2 \mathrm{~B}$ \\
\hline $10.0 \mathrm{~cm}$ & $39.3 \pm 11.6 \mathrm{C}$ & $36.2 \pm 9.4 \mathrm{C}$ \\
\hline
\end{tabular}

*Means of harvest time followed by the same letters in the column are not different by Tukey test $(\alpha=0.05)$ (médias de época de colheita seguidas de mesma letra na coluna não diferem pelo teste de Tukey $(\alpha=0,05)$ ) (médias de época de colheita seguidas de mesma letra na coluna não diferem pelo teste de Tukey $(\alpha=0,05)) ; * *$ Means of line spacing followed by the same letters in the column are not different by Tukey test $(\alpha=0.05)$ (médias de distancia entre linhas, na coluna, não diferem pelo teste de Tukey $(\alpha=0,05))$. in the $2^{\text {nd }}$ year (data not shown). This indicates that Esplanada might respond to higher plant density differently than SugarSnax 54. However, due to the large variation in the data set, especially in the first year, these conclusions should be taken with care and further investigation is under way.

Although it didn't affect total yield, decreasing line spacing from $16.6 \mathrm{~cm}$ to $10.0 \mathrm{~cm}$ was important to assure that a larger proportion of thinner roots was produced what is necessary for the production of superior quality Cenouretes $^{\circledR}$. There were significant effects of line spacing on yield of roots most suited for Cenourete ${ }^{\circledR}$ production (lower than $25 \mathrm{~mm}$ diameter) and this effect was different for each cultivar. The yield of SugarSnax 54 roots in all size categories was influenced by line spacing and this effect was independent of harvest time and year. There were

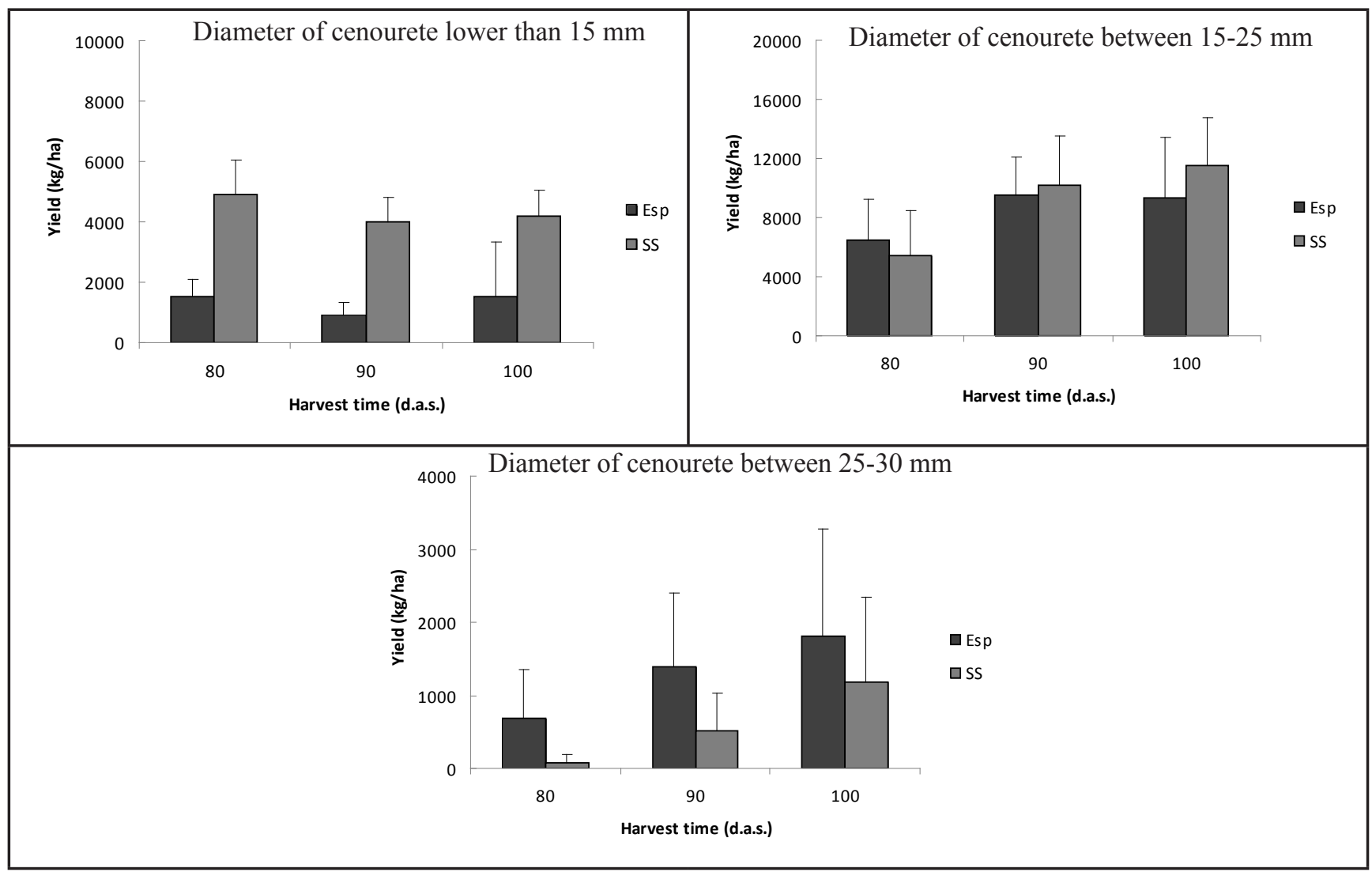

Figure 1. Yield of Cenourete ${ }^{\circledR}$ from carrot cultivar Esplanada (ESP) and SugarSnax 54 (SS) as influenced by harvest time when planted at $16.6 \mathrm{~cm}$ line spacing. Cenouretes ${ }^{\circledR}$ were classified according to the widest diameter in classes $<15$ (wider diameter lower than $15 \mathrm{~mm}$ ); 15-25 (wider diameter between 15-25 mm); 25-30 (wider diameter between 25-30 mm). Data are the average + standard deviation of 2 years and 4 replicates (rendimento de Cenourete ${ }^{\circledR}$ obtida das cultivares de cenoura Esplanada (ESP) e SugarSnax 54 (SS) em função da época de colheita, quando plantada com espaçamento de 16,6 cm entre linhas. As Cenouretes ${ }^{\circledR}$ foram classificadas quanto ao diâmetro máximo nas classes < 15 (diâmetro máximo inferior a 15 mm); 15-25 (diâmetro máximo entre 15 e 25 mm); 25-30 (diâmetro máximo entre 25-30 mm). Os dados são a média + desvio padrão de 2 anos e 4 repetições). Brasília, Embrapa Hortaliças, 2007-2008. 


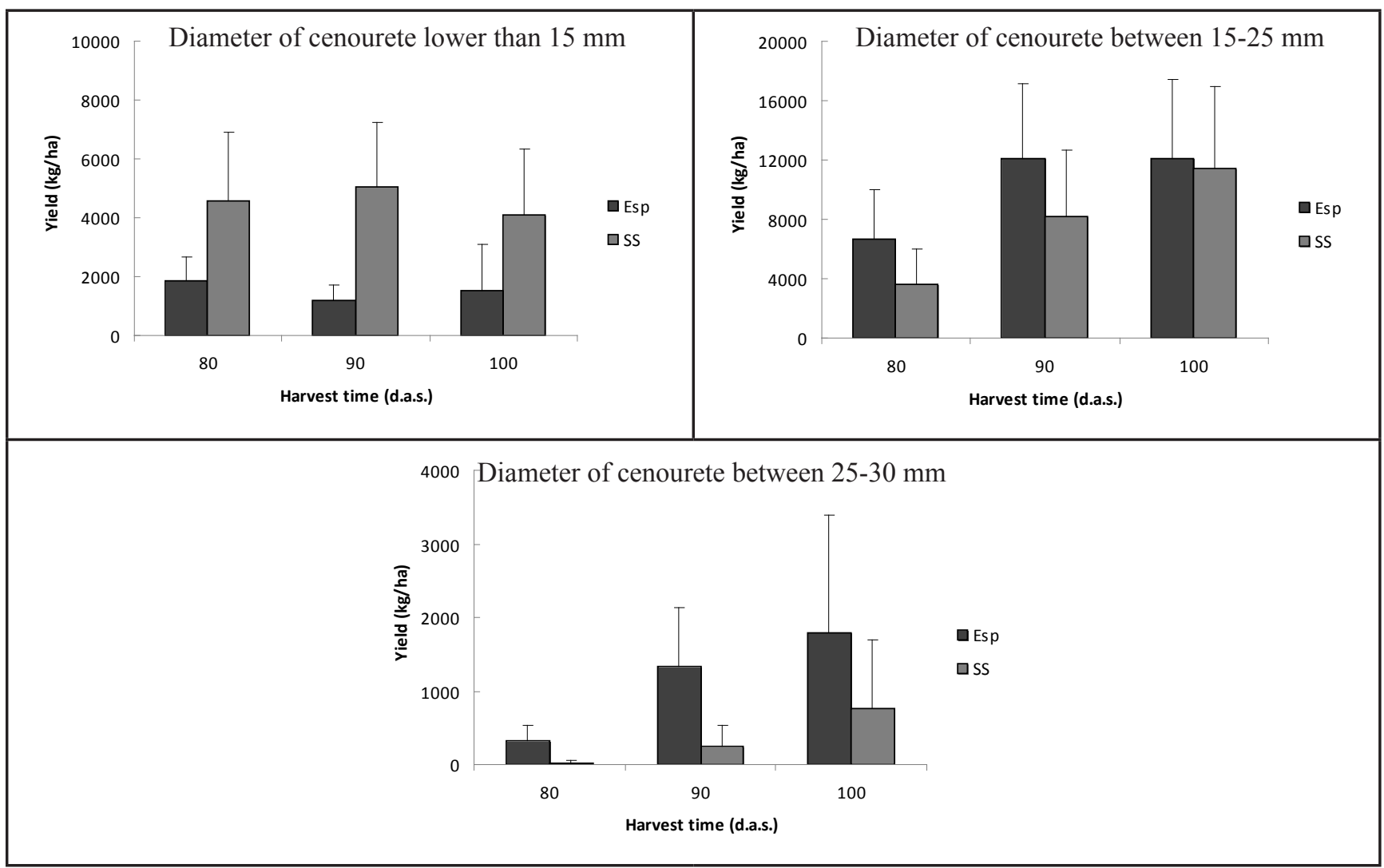

Figure 2. Yield of Cenourete ${ }^{\circledR}$ from carrot cultivar Esplanada (ESP) and SugarSnax 54 (SS) as influenced by harvest time when planted at $12.5 \mathrm{~cm}$ line spacing. Cenouretes ${ }^{\circledR}$ were classified according to the widest diameter in classes $<15$ (wider diameter lower than $15 \mathrm{~mm}$ ); 15-25 (wider diameter between 15-25 mm); 25-30 (wider diameter between 25-30 mm). Data are the average + standard deviation of 2 years and 4 replicates (rendimento de Cenourete ${ }^{\circledR}$ obtida das cultivares de cenoura Esplanada (ESP) e SugarSnax 54 (SS) em função da época de colheita, quando plantada com espaçamento de $12,5 \mathrm{~cm}$ entre linhas. As Cenouretes ${ }^{\circledR}$ foram classificadas quanto ao diâmetro máximo nas classes < 15 (diâmetro máximo inferior a 15 mm); 15-25 (diâmetro máximo entre 15 e 25 mm); 25-30 (diâmetro máximo entre 25-30 mm). Os dados são a média + desvio padrão de 2 anos e 4 repetições). Brasília, Embrapa Hortaliças, 2007-2008.

significant interactions between the effects of line spacing and harvest time and year only for Esplanada cultivar.

Mean root weight and mean root length - SugarSnax 54 roots were longer than Esplanada roots for all treatments. An unwanted effect of decreasing line spacing, and concomitantly increasing plant density, was the decrease in root length for both cultivars. At $16.6 \mathrm{~cm}$ line spacing, Esplanada and SugarSnax 54 root length was $17.2 \pm 1.7 \mathrm{~cm}$ and $22.1 \pm 2.9 \mathrm{~cm}$ respectively. When the line spacing decreased to $10 \mathrm{~cm}$, root length decreased to $15.7 \pm 1.4 \mathrm{~cm}$ and $19.9+2.5$ $\mathrm{cm}$, respectively. However, when the average root length was regressed against actual plant density, there was no significant relationship between both (data not shown). Increased plant density from 64 to 128 plants $/ \mathrm{m}^{2}$ also resulted in significant decrease in length of carrots Alvorada and Carandaí (Luz et al., 2008) and the average root length of Caropack cultivar decreased when plant density increased from $197 \mathrm{pl} / \mathrm{m}^{2}$ to 321 $\mathrm{pl} / \mathrm{m}^{2}$ (Lazcano et al., 1998). Although significant, the decrease in length in the present experiment had a small impact in Cenourete ${ }^{\circledR}$ production since roots are cut into $60 \mathrm{~mm}$ long segments and on average the decrease in length was lower than $25 \mathrm{~mm}$. This means that from a root $120 \mathrm{~mm}$ long two processable root pieces are obtained. Now from a root 70 to $110 \mathrm{~mm}$ long only one processable piece is obtained together with a waste piece 10 to $50 \mathrm{~mm}$ long respectively.

Line spacing and duration of growth were important factors influencing mean root weight and both longer cycle and larger line spacing resulted in higher weight for both cultivars (Table 2). Plant competition effects are reflected in a lower relative growth rate of the plants of the high density treatments
(Salter et al., 1979; Salter et al., 1981; Rajasekaran, et al., 2006). Salter et al. (1979) using a range of line systems concluded that plant spatial arrangement had little effect on root yield but plant density and time of harvest were the most important variables controlling mean root size and hence the yield of roots at any particular size grade. Bleasdale (1973) showed that even when similar total yields were obtained from both wide and close lines, the close lines had a higher proportion of thinner roots. A grower adopting $42 \mathrm{~cm}$ line spacing could expect to have about $25 \%$ less canning-carrots suitable for processing compared with lines $15 \mathrm{~cm}$ apart.

Yield of $60 \mathrm{~mm}$ long root pieces - The total production of $60 \mathrm{~mm}$ long carrot pieces with the widest diameter lower than $30 \mathrm{~mm}$, the raw material for Cenourete ${ }^{\circledR}$ production, 


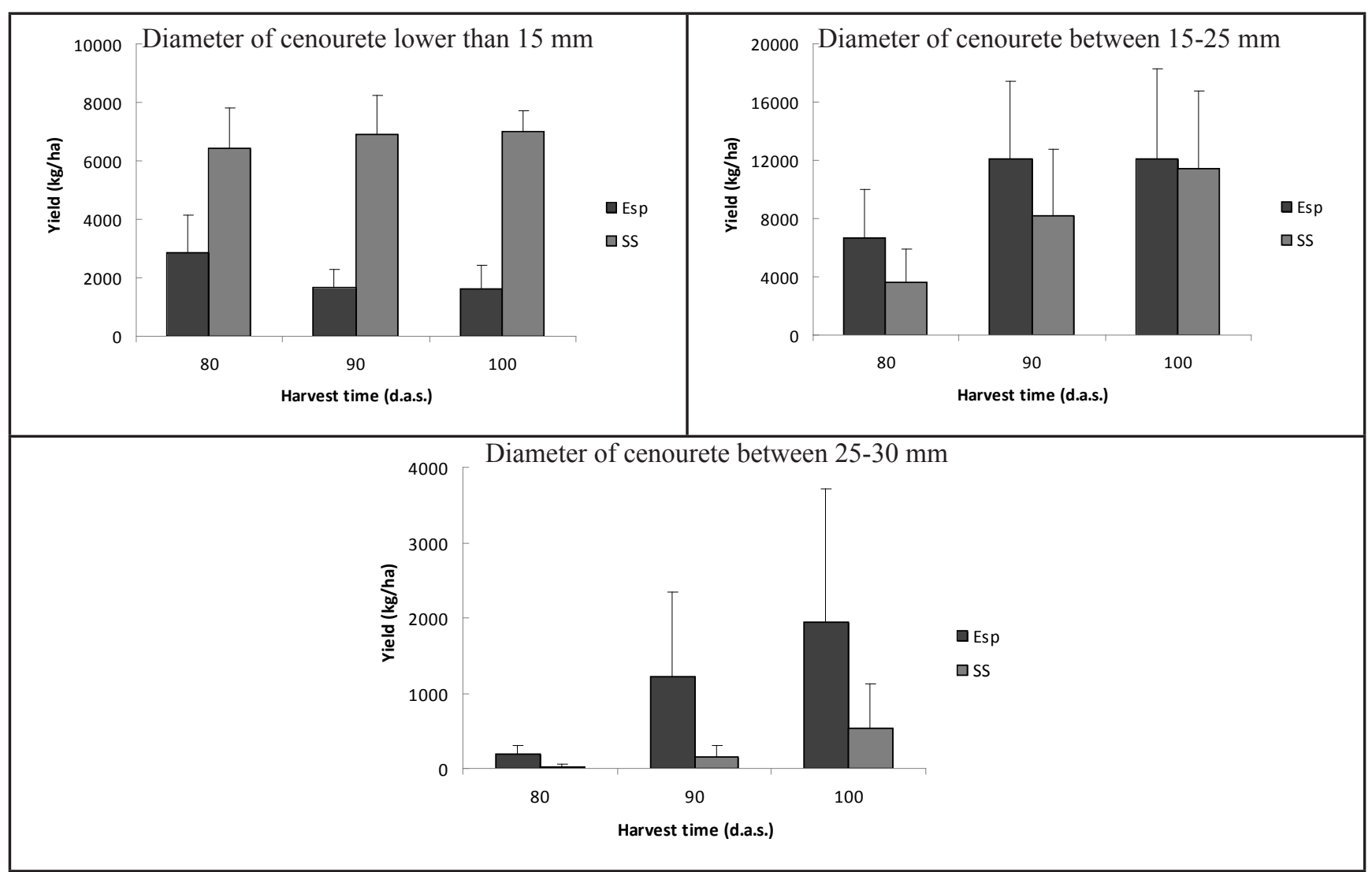

Figure 3. Yield of Cenourete ${ }^{\circledR}$ from carrot cultivar Esplanada (ESP) and SugarSnax 54 (SS) as influenced by harvest time when planted at $10.0 \mathrm{~cm}$ line spacing. Cenouretes ${ }^{\circledR}$ were classified according to the widest diameter in classes $<15$ (wider diameter lower than $15 \mathrm{~mm}$ ); 15-25 (wider diameter between 15-25 mm); 25-30 (wider diameter between 25-30 mm). Data are the average + standard deviation of 2 years and 4 replicates (rendimento de Cenourete ${ }^{\circledR}$ obtida das cultivares de cenoura Esplanada (ESP) e SugarSnax 54 (SS) em função da época de colheita, quando plantada com espaçamento de 10,0 cm entre linhas. As Cenouretes ${ }^{\circledR}$ foram classificadas quanto ao diâmetro máximo nas classes < 15 (diâmetro máximo inferior a 15 mm); 15-25 (diâmetro máximo entre 15 e 25 mm); 25-30 (diâmetro máximo entre 25-30 mm). Os dados são a média + desvio padrão de 2 anos e 4 repetições). Brasília, Embrapa Hortaliças, 2007-2008.

was influenced by all the main effects and no interaction was significant in the analysis of both cultivars. The yield increased at later harvests and production in the second year was higher for all treatments compared with the first year. Difference between means of line spacing treatments were not significant by Tukey ( $\alpha=0.05$; data not shown). As reported for root yield, although line spacing did not influence the total yield of root pieces, it was important in determining the relative amount of a particular size grade.

When the root pieces were graded and each class was analysed separately, the effect of line spacing was significant for the majority of the classes. Decreasing line spacing resulted in higher production of superior quality pieces (diameter lower than 25 $\mathrm{mm}$ ) from Esplanada cultivar (Table
3). SugarSnax 54 cultivar was less influenced by line spacing and 10 $\mathrm{cm}$ line spacing resulted in higher production of $<15 \mathrm{~mm}$ diameter pieces but not of 15-25 mm diameter pieces. Delaying harvest from 80 to 90 d.a.s. decreased the production of $<15 \mathrm{~mm}$ pieces and increased the production of 15-25 mm pieces for both cultivars. Prolonging the cycle to 100 d.a.s. did not result in significant changes in yield (Table 3).

Cenourete $^{\circledR}$ yield - Total and marketable yield of Cenourete ${ }^{\circledR}$ followed the same trend for both cultivars and only the results of the marketable yield will be presented. Yield from cultivar Esplanada was affected by the main effects of harvest time $(\operatorname{Pr}>\mathrm{F}=<0.0001)$, line spacing $(\operatorname{Pr}>\mathrm{F}=0.0036)$ and year $(\operatorname{Pr}>\mathrm{F}=<0.0001)$. Yield from cultivar SugarSnax 54 followed the same trend except for a marginal effect of the interaction harvest time* year $(\mathrm{Pr}>\mathrm{F}=$ $0.0384)$. This interaction explained less than $3 \%$ of the variation in the data set, and because of that, was not further investigated. Levels of significance for the main effects of harvest time, plant density and year were respectively $\operatorname{Pr}>\mathrm{F}=<0.0001 ; \operatorname{Pr}>\mathrm{F}=0.0005$ and $\operatorname{Pr}>\mathrm{F}=<0.0001$.

The marketable yield of Cenourete ${ }^{\circledR}$ increased when harvest was delayed from 80 to 90 d.a.s. (Table 4). Prolonging the cycle to 100 days had no significant effect on total yield but clearly increased the proportion of large Cenouretes ${ }^{\circledR}$ (Figure 1-3). For Esplanada cultivar it included a large proportion of those in the range $25-30 \mathrm{~mm}$ diameter that are likely to be rejected in markets where this product is consumed as a raw snack. Delaying harvest also significantly 
Table 3. Effect of line spacing and harvest time on yield of $6 \mathrm{~cm}$ long carrot pieces suitable for Cenourete ${ }^{\circledR}$ production, from cultivar Esplanada and SugarSnax 54. Harvest time data are the average \pm standard deviation of 3 line spacings, 2 years and 4 replicates. Line spacing data are the average \pm standard deviation of 3 harvest times, 2 years and 4 replicates (efeito da distância entre linhas e da época de colheita sobre a produção de toletes de cenoura com $6 \mathrm{~cm}$ de comprimento, adequados para produção de Cenourete ${ }^{\circledR}$, obtidos das cultivares Esplanada e SugarSnax 54). Os dados de época de colheita são a média \pm desvio padrão de 3 distâncias entre linhas, 2 anos e 4 repetições. Os dados de distância entre linhas são a média \pm desvio padrão de 3 épocas de colheita, 2 anos e 4 repetições). Brasília, Embrapa Hortaliças, $2007-2008$.

\begin{tabular}{|c|c|c|c|c|c|c|}
\hline & \multicolumn{3}{|c|}{ Esplanada (kg/ha) } & \multicolumn{3}{|c|}{ SugarSnax 54 (kg/ha) } \\
\hline & $15 \mathrm{~mm}$ & $15-25 \mathrm{~mm}$ & $25-30 \mathrm{~mm}$ & $15 \mathrm{~mm}$ & $15-25 \mathrm{~mm}$ & $25-30 \mathrm{~mm}$ \\
\hline \multicolumn{7}{|c|}{ Harvest time* } \\
\hline 80 d.a.s & $1,069 \pm 752 \mathrm{~A}$ & $11,569 \pm 4,851 \mathrm{~B}$ & $9,064 \pm 4,688 \mathrm{~A}$ & $4,366 \pm 1,401 \mathrm{~A}$ & $11,562 \pm 5,025 \mathrm{~B}$ & $\overline{6,463 \pm 5,129 \mathrm{~A}}$ \\
\hline 90 d.a.s & $453 \pm 278 \mathrm{~B}$ & $13,495 \pm 6,103 \mathrm{~A}$ & $8,609 \pm 6,687 \mathrm{~A}$ & $3,133 \pm 1,482 \mathrm{~B}$ & $16,994 \pm 6,156 \mathrm{~A}$ & $4,702 \pm 5,327 \mathrm{~A}$ \\
\hline 100 d.a.s. & $399 \pm 326 \mathrm{~B}$ & $12,275 \pm 5,643 \mathrm{~A}$ & $9,169 \pm 6,935 \mathrm{~A}$ & $3,144 \pm 1,314 \mathrm{~B}$ & $20,082 \pm 6,198 \mathrm{~A}$ & $4,303 \pm 4,563 \mathrm{~A}$ \\
\hline \multicolumn{7}{|c|}{ Line spacing** } \\
\hline $16.6 \mathrm{~cm}$ & $401 \pm 270 \mathrm{~B}$ & $9,812 \pm 2,936 \mathrm{~B}$ & $3,245 \pm 2,495 \mathrm{C}$ & $2,796 \pm 1,121 \mathrm{~B}$ & $14,906 \pm 3,859 \mathrm{~A}$ & $545 \pm 793 \mathrm{C}$ \\
\hline $12.5 \mathrm{~cm}$ & $557 \pm 419 \mathrm{~B}$ & $12,062 \pm 5,364 \mathrm{AB}$ & $10,086 \pm 3,918 \mathrm{~B}$ & $3,252 \pm 1,484 \mathrm{~B}$ & $15,124 \pm 7,708 \mathrm{~A}$ & $4,733 \pm 3,335 \mathrm{~B}$ \\
\hline $10.0 \mathrm{~cm}$ & $962+784 \mathrm{~A}$ & $15,465 \pm 6,348 \mathrm{~A}$ & $13,511 \pm 6,032 \mathrm{~A}$ & $4,295 \pm 1,283 \mathrm{~A}$ & $18,609 \pm 7,555 \mathrm{~A}$ & $10,190 \pm 4,207 \mathrm{~A}$ \\
\hline
\end{tabular}

*Means of harvest time followed by the same letters in the column are not different by Tukey test ( $\alpha=0.05)$ (médias de época de colheita seguidas de mesma letra na coluna não diferem pelo teste de Tukey $(\alpha=0,05))$;**Means of line spacing followed by the same letters in the column are not different by Tukey test ( $\alpha=0.05$ ) (médias de distancia entre linhas, na coluna, não diferem pelo teste de Tukey $(\alpha=0,05)$ ).

Table 4. Effect of line spacing and harvest time on yield of Cenourete ${ }^{\circledR}$ from cultivar Esplanada and SugarSnax 54. Harvest time data are the average \pm standard deviation of 3 plant densities, 2 years and 4 replicates. Line spacing data are the average \pm standard deviation of 3 harvest times, 2 years and 4 replicates (efeito da distância entre linhas e da época de colheita sobre a produção de Cenourete ${ }^{\circledR}$ (kg/ha) obtidos das cultivares Esplanada e SugarSnax 54. Os dados de época de colheita são a média \pm desvio padrão de 3 distâncias entre linhas, 2 anos e 4 repetições. Os dados de distância entre linhas são a média \pm desvio padrão de 3 épocas de colheita, 2 anos e 4 repetições). Brasília, Embrapa Hortaliças, 2007-2008.

\begin{tabular}{lcc}
\hline & Esplanada (kg/ha) & SugarSnax 54 (kg/ha) \\
\hline 80 d.a.s & & Harvest time* \\
90 d.a.s. & $9,374 \pm 3,949 \mathrm{~B}$ & $9,936 \pm 3,972 \mathrm{~B}$ \\
100 d.a.s. & $13,804 \pm 5,480 \mathrm{~A}$ & $14,997 \pm 5,211 \mathrm{~A}$ \\
\hline & $15,189 \pm 6,553 \mathrm{~A}$ & $18,250 \pm 6,539 \mathrm{~A}$ \\
\hline $16.6 \mathrm{~cm}$ & & Line spacing** \\
$12.5 \mathrm{~cm}$ & $11,056 \pm 3,865$ & $14,002 \pm 4,523$ \\
$10.0 \mathrm{~cm}$ & $12,943 \pm 6,347$ & $12,655 \pm 7,086$ \\
\hline
\end{tabular}

*Means of harvest time followed by the same letters in the column are not different by Tukey test $(\alpha=0.05)$ (médias de época de colheita seguidas de mesma letra na coluna não diferem pelo teste de Tukey $(\alpha=0,05))$; **Means of line spacing in the column are not different by Tukey test $(\alpha=0.05)$ (médias de distancia entre linhas, na coluna, não diferem pelo teste de Tukey $(\alpha=0,05)$ ).

increased the production of waste, since any portion of the root larger than 30 mm diameter is not used in Cenourete ${ }^{\circledR}$ production and is regarded as waste. When the roots were harvested 80 d.a.s. both Esplanada and SugarSnax 54 produced about $2.5 \mathrm{t} / \mathrm{ha}$ of cut waste. As harvest was delayed to 100 d.a.s., Esplanada produced double the amount of waste compared to SugarSnax 54, respectively $11.5 \mathrm{t} / \mathrm{ha}$ and $5.3 \mathrm{t} / \mathrm{ha}$, and this difference was due mainly to differences in the amount of root pieces larger than $30 \mathrm{~mm}$ diameter.

Cenourete ${ }^{\circledR}$ yield increased numerically with higher density but these differences were not significant by Tukey test $(\alpha=0.05)$. Regression of Cenourete $^{\circledR}$ yield against actual plant density showed no consistent results (data not shown) despite of a weak tendency for higher yields of cultivar Esplanada at higher plant density.

However, line spacing and harvest time were important to determine the proportion of Cenourete ${ }^{\circledR}$ in each class size. When planted at $10 \mathrm{~cm}$ line spacing and harvested 80 d.a.s, SugarSnax 54 produced $56 \%$ of Cenourete ${ }^{\circledR}$ weight in the class $<15 \mathrm{~mm}$; when harvest was delayed to 100 d.a.s. this proportion decreased to $34 \%$ (Figure 3). Under the same conditions, the production of $<15$ mm Cenourete ${ }^{\circledR}$ from Esplanada decreased from $28 \%$ to $9 \%$ and concomitantly the production of 25-30 $\mathrm{mm}$ Cenourete ${ }^{\circledR}$ increased from 1.5 to $9 \%$. The proportion of Cenourete ${ }^{\circledR}$ in the class 15-25 mm was less influenced by both factors, since any condition that would result in $<15 \mathrm{~mm}$ Cenourete ${ }^{\circledR}$ migrating to the $15-25 \mathrm{~mm}$ class would be somehow compensated by $15-25$ mm Cenouretes ${ }^{\circledR}$ migrating to the $25-30$ mm class. 
In a previous report, Cenourete ${ }^{\circledR}$ yield from Esplanada varied from $2.4+0.4$ to $10.7 \pm 1.7 \mathrm{t} / \mathrm{ha}$ (Silva et al., 2008c) while in the present report the Cenourete ${ }^{\circledR}$ yield from the same cultivar varied from $9.4 \pm 3.9$ to $15.2 \pm 6.5 \mathrm{t} / \mathrm{ha}$. In general, the yield of Cenourete ${ }^{\circledR}$ from SugarSnax 54 cultivar was numerically higher than that obtained from Esplanada. This difference in favor of SugarSnax 54 varied from $6 \%$ to $20 \%$ depending on the treatment and was larger the later the harvest and the higher the plant density. The higher production of Cenourete ${ }^{\circledR}$ was found, for both cultivars, in the class $15-25 \mathrm{~mm}$ diameter and varied from 3,000 to $18,000 \mathrm{~kg} / \mathrm{ha}$ depending on treatment. The production of Cenourete ${ }^{\circledR}$ smaller than $15 \mathrm{~mm}$ varied from 700 to $8,000 \mathrm{~kg} / \mathrm{ha}$ and in the class $25-30 \mathrm{~mm}$ it varied from 0 to $3,000 \mathrm{~kg} / \mathrm{ha}$ depending on treatment (Figure 1-3)

It should be stressed that the yields reported here were obtained under dry winter conditions in the central region of Brazil (15'47'S and 47 $55^{\prime} \mathrm{W}$ ). Under rainy summer conditions SugarSnax 54 is not competitive due to its high susceptibility to foliar diseases while Esplanada can be cultivated all over the year in the main carrot producing regions in Brazil. Additionally, seed germination of SugarSnax 54 was showed to be very low under high temperature (Nascimento et al., 2008) what is an additional limitation to its cultivation in the summer time.

The results presented here show that both cultivars, Esplanada and SugarSnax 54, can be cultivated under winter conditions in the Central region of Brazil, for the production of Cenourete ${ }^{\circledR}$. In order to increase Cenourete ${ }^{\circledR}$ yield, harvest time and plant density should be optimized to enhance the production of thinner roots.

The best combination plant density $x$ harvest time for Esplanada and
SugarSnax 54 under the conditions of this experiment will depend whether the interest lies in the production of any or of a particular Cenourete ${ }^{\circledR}$ size. If any size under $30 \mathrm{~mm}$ diameter is acceptable, higher yield will be obtained when the roots are harvested after 90 d.a.s.. In this case, the effect of line spacing from 10 to $16.6 \mathrm{~cm}$ does not influence yield significantly. If the interest lies in Cenourete ${ }^{\circledR}$ smaller than $25 \mathrm{~mm}$ the carrots should be harvested not longer than 90 d.a.s. (Esplanada) or between 90-100 d.a.s. (SugarSnax 54) and $10 \mathrm{~cm}$ line spacing should be used. However, one must take into account that growth time dependence varies between environments (Reid \& English, 2000) as much as the interactions between harvest time and plant density. In practice it means that the best harvest time and plant density to optimize Cenourete ${ }^{\circledR}$ yield must be adjusted in regions where edaphoclimatic conditions differ from those encountered here.

\section{ACKNOWLEDGEMENTS}

The author is grateful to Dr. Jairo V. Vieira and Dr. João Bosco C. da Silva from Embrapa Vegetables for their assistance in designing the experiments and for supplying the seeds.

\section{REFERENCES}

BLEASDALE JKA. 1973. Control of size and yield in relation to harvest date of carrot roots. Acta Horticulturae 27: 134-142.

HATCHER L; STEPANSKI EJ; 1994. A Stepby-Step Approach to Using SAS System for Univariate and Multivariate Statistics. SAS Institute Inc., Gary, N.C. p.215.

LANA MM; SILVA JBC; Vieira JV. 2007 Cenourete $^{\circledR}$ and Catetinho ${ }^{\circledR}$ - Brazilian Minicarrots. Brazilian Journal of Food Techology 10: 169-175.

LAZCANO CA; DAINELLO FJ; PIKE LM; MILLER ME; BRANDEBERGER L; BAKER LR; 1998. Seed lines, population density, and root size at harvest affect quality and yield of cut-and-peel baby carrots. HortScience 33: 972-975.

LUZ JMQ; CALABRIA IP; VIEIRA JV; MELO B; SANTANA DG; SILVA MAD; 2008. Densidade de plantio de cultivares de cenoura para processamento submetidas à adubações química e orgânica. Horticultura Brasileira 26: 276-280.

NASCIMENTO WM; VIEIRA JV; SILVA GOS; REISTMA K; CANTLIFFE DJ. 2008. Carrot seed germination at high temperature: effect of genotype and association with ethylene production. HortScience 43: 1538-1543.

RAJASEKARAN LR; ASTATKIE T; CALDWELL C. 2006. Seeding rate and seed spacing modulate root yield and recovery of slicer and dicer carrots differently. Scientia Horticulturae 107: 319-324.

REID JB; ENGLISH JM. 2000. Potential yield in carrots (Daucus carota L.): Theory, test, and an application. Annals of Botany 85: 593-605.

SALTER PJ; CURRAH IR; FELLOWS JR. 1979. The effects of plant density, spatial arrangement and time of harvest on yield and root size in carrots. Journal of Agricultural Science 93: 431-440.

SALTER PJ; CURRAH IR; FELLOWS JR. 1980. Further studies on the effects of plant density, spatial arrangement and time of harvest on yield and root size in carrots. Journal of Agricultural Science 94: 465-478.

SALTER PJ; CURRAH IR; FELLOWS JR. 1981. Studies on some sources of variation in carrot root weight. Journal of Agricultural Science 96: 549-556

SILVA JBC; LANA MM; VIEIRA JV. 2008a. Equipamentos para agroindústria de minicenouras Cenourete e Catetinho: 1. Cortadoras - Comunicado Técnico, 2008, 14 p. (Embrapa Hortaliças; Comunicado Técnico; 60), avaialable at http:/www.cnph.embrapa.br/ paginas/serie_documentos/publicacoes2008/ cot_60.pdf

SILVA JBC; LANA MM; VIEIRA JV. 2008b. Equipamentos para agroindústria de mini-cenouras Cenourete e Catetinho: 3. Processadoras - Comunicado Técnico, 2008, 11 p. (Embrapa Hortaliças; Comunicado Técnico; 58) available at http://www.cnph. embrapa.br/paginas/serie documentos/ publicacoes2008/cot_58.pdf

SILVA JBC; VIEIRA JV; LANA MM. 2008c. Processing yield of the carrot cultivar Esplanada as affected by harvest time and planting density. Scientific Horticulture 115: 218-222. 